might have been remembered only by scholars, attracted uniquely widespread condemnation, with Byron's voice not merely soaring above the contemporary chorus in Britain, but speaking to Greeks as well, and to every later generation in both countries.

The kind of internationalist spirit that protested then is still quietly at work today: it will never go away. In the long run, there can only be one end to such a story.

A. M. Snodgrass is at the Faculty of Classics,

University of Cambridge, Cambridge

CB3 9DA, UK.

\section{Civilized living}

\section{Cities for a Small Planet}

by Richard Rogers

Faber: 1997. Pp. 180. £9.99 (pbk)

\section{Roy Porter}

Cities are certainly the most conspicuous symptoms of our global environmental crisis, and perhaps even the chief cause. One statistic will here suffice - with its 20 million inhabitants and four million cars, Mexico City is growing at the rate of 80,000 people a month - and also one grim reminder: all previous great urban civilizations, from those of the Indus valley, the Tigris and Euphrates onwards, have utterly collapsed.

Cities for a Small Planet, an exquisitely designed and illustrated reworking of Richard Rogers' 1995 BBC radio Reith lectures, tackles the environmental costs of cities, while affirming their human potential. Cities are meant to bring civilization, but all too often today it is pollution, poverty, crime, congestion and chaos that they call to mind: hence the flight to greenfield sites. So: what future for our cities? And specifically, asks Rogers, where do architects stand in all this - are they sinners, scapegoats or saviours?

Recent decades have seen cities compromised by market-driven developments sterile zoning into 'single-minded' spaces such as business parks and out-of-town shopping malls - and wounded by the great gashes made by highways. Today's megacity may be bejewelled by the odd breathtaking postmodernist tower, but (especially in the United States) it has turned its back on the public areas people crave and urban vitality demands. All too often, Rogers admits, the architect or planner has been the villain of the piece, or at least supinely complicit in the making of these urban wastelands.

How could we expect otherwise, when the profession is typically paid to produce not integrated spaces but blocks, in one-off commissions from property developers? "Buildings of all types are packaged and standardized," Rogers concedes. "Architects are selected for their low fees rather than for the

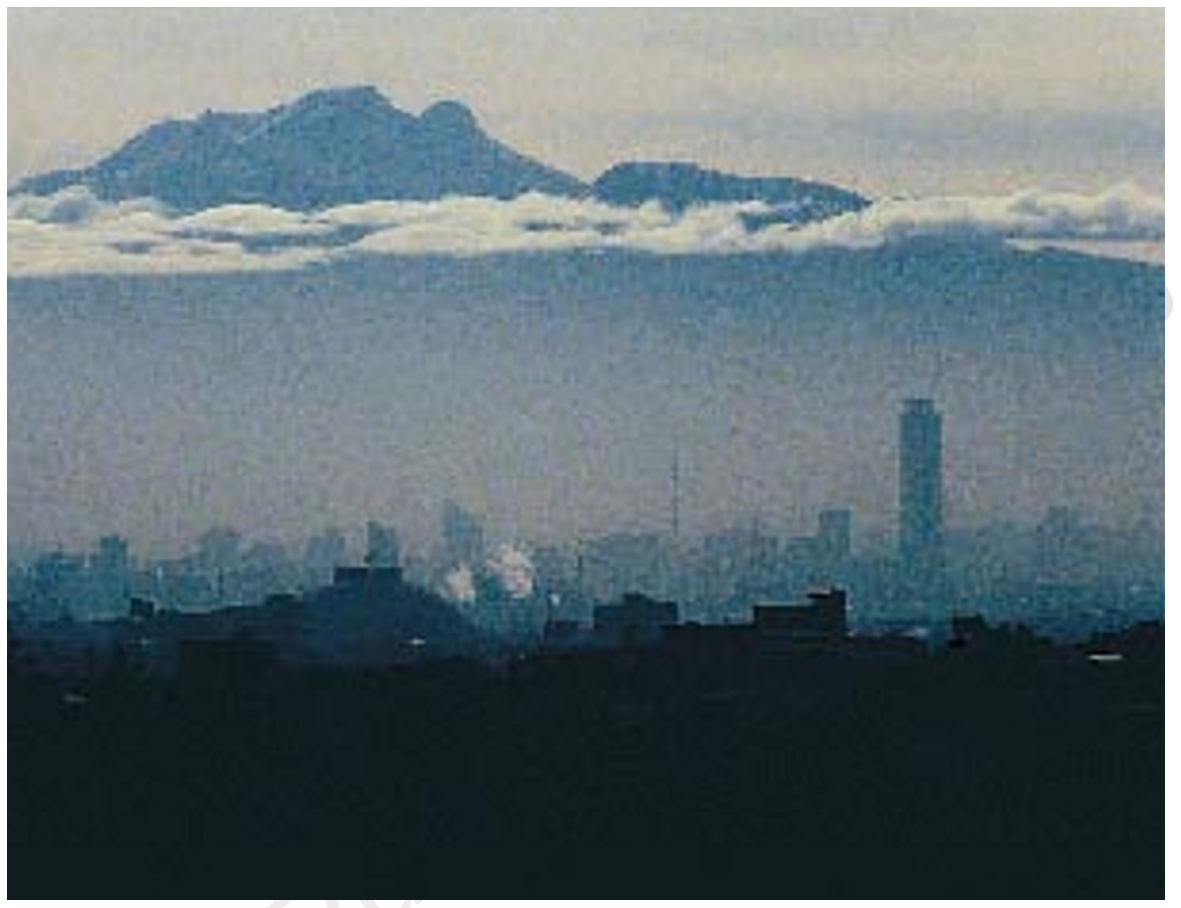

Under a cloud: are sprawls such as pollution-plagued Mexico City heading for disaster? Four million cars congest its streets and its population of 20 million is growing at the rate of 80,000 people a month.

quality of their work. The profession is condemned to turning out the largest enclosure for the least money in the shortest time ... these buildings are the energy-guzzling structures that are consuming half of the world's annual energy." The result? Buildings that enrich clients but impoverish the quality of urban living.

In place of today's characteristic laissezfaire sprawl, Rogers argues the case for the compact city, one with multiple and overlapping functions, and endowed with ample people-friendly public sites. To achieve this, public will is needed, as in the showcase postFranco renewal of Barcelona in the 1980s under the populist mayor Pascal Maragal. By contrast, London, rudderless since the abolition of the Greater London Council, is collapsing amid worsening traffic congestion and pollution which carry economic as well as health costs.

Architect-planners have their role to play too. Given today's desiderata of sustainable growth and environmental renewal, the city and its structures must be rethought on viable ecological principles. Essential to that are energy-efficient buildings, whose specialized technical features will use natural resources (trees, sunlight, wind) and minimize waste.

Escorting the reader through a portfolio of buildings and developments mainly designed by his own partners, Rogers shows what has been done (efficient use of the atrium, for instance) and what remains to be achieved. It is disappointing that his most environmentally sympathetic proposals such as those for Shanghai - seem to be the ones that never got off the drawing-board, presumably because they contravened the developers' demand for profit-maximization and the conventional urban-political axiom that the motorist always comes first.

Londoners in particular will welcome another chance to ponder his imaginative plans for Trafalgar Square (now, as he remarks, just a vast roundabout) — though they may not be able to avoid a wry smile, given his own involvement with the Greenwich Dome, when Rogers says that, by way of a Millennium celebration, a "series of local projects" would be far preferable to a "sweeping Beaux Arts masterplan".

Mammon of course has always been the ultimate foe, but the most destructive force this century has been the car. Every redesigning of the city to make it subservient to the needs of private vehicles has been another nail in its coffin as an agent of human congregation: all too often, all that is left of public space is the unsafe, frenetic pavement. Rogers is at his most passionate in crusading to reclaim the city from the car - whether through big improvements in public transportation systems or, better still, by cutting the need for journeys themselves, for example by 'living above the shop'.

Read this book while stuck in the traffic jam on the way to work. Think of all the friendlier urban environments in which you might be reading it. And then make waves towards putting into effect the ideas so imaginatively, so ardently advanced. We owe it to the next generation that it should have no mean city to inherit.

Roy Porter is at the Wellcome Institute for the History of Medicine, 183 Euston Road, London NW1 2BE, UK. 